Check for updates

Cite this: RSC Adv., 2018, 8, 41810

Received 24th October 2018 Accepted 30th November 2018

DOI: $10.1039 / \mathrm{c} 8 \mathrm{ra0} 8822 \mathrm{e}$

rsc.li/rsc-advances

\section{Potential antihyperlipidemic polyketones from endophytic Diaporthe sp. JC-J7 in Dendrobium nobile $\uparrow$}

Ming Hu, $\$^{a}$ Xue-Qiong Yang, $\dot{t}^{\mathrm{a}}$ Chuen-Ping Wan, ${ }^{\mathrm{b}}$ Bang-Yan Wang, ${ }^{a}$ Hai-Yue Yin, ${ }^{a}$ Li-Jiao Shi, ${ }^{a}$ Ya-Mei Wu, ${ }^{a}$ Ya-Bin Yang, (D) *a Hao Zhou ${ }^{a}$ and Zhong-Tao Ding (D) *a

Eleven new polyketones named diaporthsins A-K (1-11) were isolated from the fermentation of Diaporthe sp. JC-J7. The chemical structures of compounds (1-11) were elucidated by spectroscopic methods including HRESIMS, 2DNMR, NMR and chemical methods. Compound 11 features an unusual acyclic polyketone-phenolic polyketone hybrid structure that integrates the characteristics of different fungal metabolites (cytosporone and multiplolide). Compound 3 was the only $\mathrm{C}_{12}$-polyketone obtained in this research. These new polyketones showed inhibitory activity on triglycerides (TG) in steatosis hepatocyte L-02 cells. Among them, compound 5 and (4E)-6,7,9-trihydroxydec-4-enoic acid displayed inhibitory activities on TG in steatotic L-02 cells with inhibition ratios of $26 \%$ and $21 \%$ at concentration of $5 \mu \mathrm{g}$ $\mathrm{mL}^{-1}$; also, inhibition ratios of 8-O-acetylmultiplolide $\mathrm{A}$ and phomopsisporone $\mathrm{A}$ at concentration of 5 $\mu \mathrm{g} \mathrm{mL} \mathrm{mL}^{-1}$ were calculated to be about $24 \%$ and $16 \%$, respectively, which were equivalent to the antihyperlipidemic activity of lovastatin. The preliminary structure-activity relationship indicated that acetyl at C-8 can increase the antihyperlipidemic activity of multiplolide A and the glycol ester and hydroxyl at C-6 can also increase the corresponding activity of diaporthsin B.

\section{Introduction}

Dendrobium nobile Lindl. is a well-known edible and medicinal plant with wide distribution in southwest and south China. ${ }^{1}$ Endophytes exist in various tissues of healthy plants. Endophytes are also believed to be a rich source of valuable and novel small molecules for drug development. ${ }^{2,3}$ Diaporthe spp. living in a wide range of hosts are often regarded as plant pathogens. ${ }^{4}$ They are known to cause diseases in a wide range of plant hosts including root and fruit rot. ${ }^{5}$ Diaporthe spp. produce a variety of metabolites with different bioactivities ${ }^{6-8}$ including antioxidant, ${ }^{9}$ cytotoxic activity, ${ }^{\mathbf{1 0}}$ and anti-Mycobacterium tuberculosis. ${ }^{\mathbf{1 1}}$ As a part of our project for searching new bioactive compounds from endophytic fungi of medical plants in the Yunnan province in China, Diaporthe sp. was collected from the stem of Dendrobium nobile Lindl. Eleven polyketones named diaporthsins A-K (1-11) (Fig. 1) were isolated from the

${ }^{a}$ Functional Molecules Analysis and Biotransformation Key Laboratory of Universities in Yunnan Province, School of Chemical Science and Technology, Yunnan University, Kunming, People's Republic of China. E-mail: ybyang@ynu.edu.cn; ztding@ynu.edu. cn

${ }^{b}$ Affiliated Hospital of Yunnan University of Traditional Chinese Medicine, Kunming 650021, PR China

$\dagger$ Electronic supplementary information (ESI) available: ${ }^{1} \mathrm{H}$ and ${ }^{13} \mathrm{C}$ NMR, HSQC, HMBC, ${ }^{1} \mathrm{H}-{ }^{1} \mathrm{H}$ COSY, ROESY, IR, UV and HR-ESIMS spectra of compounds 1-11. See DOI: $10.1039 / \mathrm{c} 8 \mathrm{ra0} 8822 \mathrm{e}$

\$ M. Hu and X. Q. Yang contributed equally to this work.

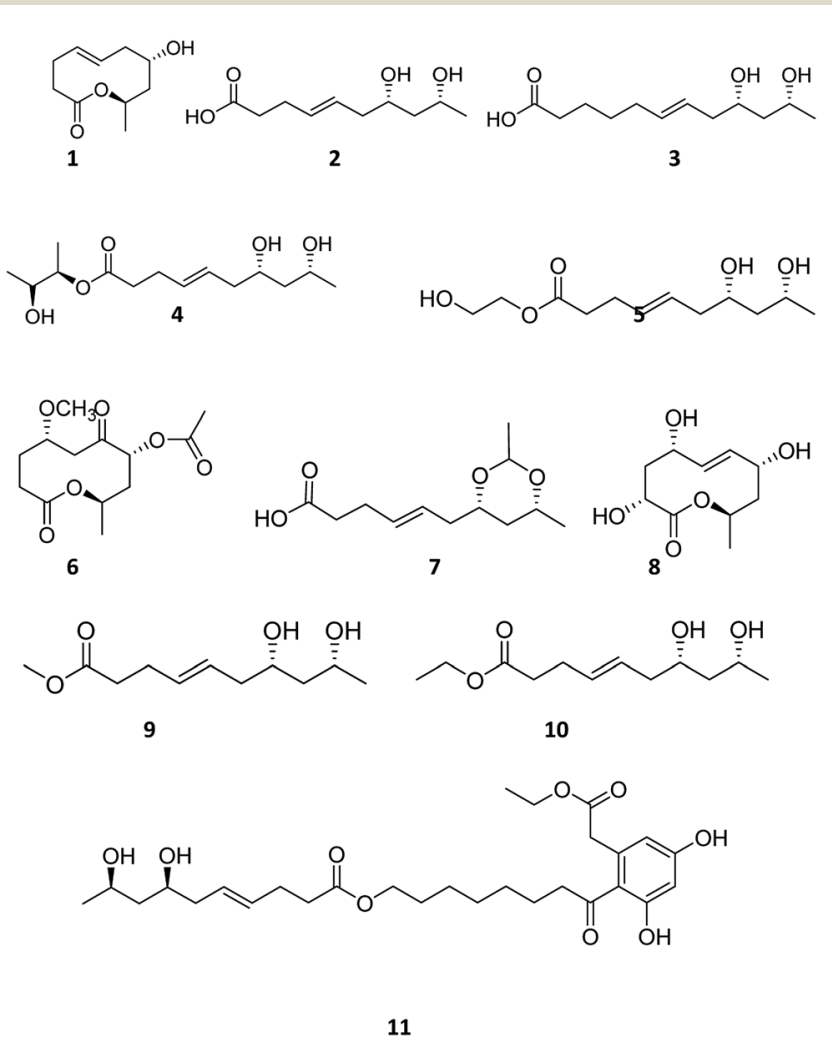

Fig. 1 The structures of the new compounds isolated from Diaporthe sp. JC-J7. 
fermentation of Diaporthe sp. JC-J7. In this paper, we report the isolation, structure elucidation and bioactivities of these new compounds.

\section{Results and discussion}

Compound $\mathbf{1}$ is a new natural product and obtained as a colorless oil; its molecular formula was determined to be $\mathrm{C}_{10} \mathrm{H}_{16} \mathrm{O}_{3}$ by analysis of its HRESI-MS spectrum and NMR data (Table 1). The NMR spectrum of $\mathbf{1}$ indicated one methyl group, four methylenes, four methines, and one carbonyl group (Table 1). The presence of a ten-membered ring was determined from the HMBC correlations from $\mathrm{H}-10$ to $\mathrm{C}-2 ; \mathrm{H}-3$ to $\mathrm{C}-2, \mathrm{C}-5 ; \mathrm{H}-4$ to $\mathrm{C}-2$, C-5, C-6; H-7 to C-5, C-6, C-9; H-8 to C-9, C-10; H-10 to C-8; H-11 to C-9, C-10 (Fig. 2). In addition, the COSY correlations of $\mathrm{H}-3 / \mathrm{H}-$ 4/H-5/H-6/H-7/H-8/H-9/H-10/H-11 also confirmed this structure. The trans orientation at C-5 and C- 6 was determined on the basis of the NOESY correlations between $\mathrm{H}-5$ and $\mathrm{H}-7$ as well as $\mathrm{H}-8$. The relative configurations of compound 1 at $\mathrm{H}-8$ and $\mathrm{H}-10$ were determined to be $c i s$ by the NOESY correlations between $\mathrm{H}^{-}$ 8 and $\mathrm{H}-9$ as well as $\mathrm{H}-9$ and $\mathrm{H}-10$. The absolute configuration of $\mathrm{C}-10$ was determined as $\mathrm{R}$ by comparing the NMR results with those of the compounds $\mathbf{2 - 1 1}$ and biogenesis. $\mathbf{1}$ was reacted with $(S)$-MTPA and $(R)$-MTPA, yielding $(S)$ - and $(R)$-MTPA ester derivatives, respectively, at OH-8. The values of $\Delta \delta=\delta_{S}-\delta_{R}$ were calculated according to NMR data analyses. For $\mathrm{H}-7$ and $\mathrm{H}-$ 9 , negative and positive $\Delta \delta$ values, respectively, were observed. Therefore, the absolute configuration at C- 8 was determined to be $S$. On the basis of these data, the structure of compound 1 was determined and named diaporthsin A.

Compound 2 was obtained as a colorless oil; its molecular formula was determined to be $\mathrm{C}_{10} \mathrm{H}_{18} \mathrm{O}_{4}$ by the analysis of its HRESI-MS spectrum and NMR data (Table 1). The ${ }^{13} \mathrm{C}-\mathrm{NMR}$ spectrum showed one methyl group, four methylenes, four methines, and one carbonyl group (Table 1). On the basis of these data, we observed that the structure of compound 2 exhibited a similar skeleton to that of (4E)-6,7,9-trihydroxydec-4enoic acid isolated in this research ${ }^{12}$ except for the absence of $\mathrm{OH}$ at $\mathrm{C}-6$ in 2 . The structure of compound 2 was confirmed by the HMBC correlations from $\mathrm{H}-2$ to $\mathrm{C}-4 ; \mathrm{H}-3$ to $\mathrm{C}-4, \mathrm{C}-5 ; \mathrm{H}-6$ to

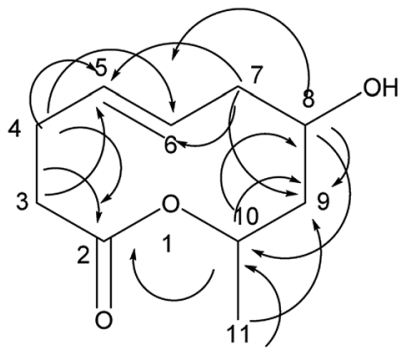

Fig. 2 The key HMBC correlations of compound 1.

C-4, C-5, C-7, C-8 (Fig. 3). The two OH groups connected to C-7 and $\mathrm{C}-9$ were determined by the HMBC correlations from $\mathrm{H}-7$ to C-5; H-9 to C-7; H-10 to C-8, C-9 (Fig. 3). The COSY correlations of $\mathrm{H}-2 / \mathrm{H}-3 / \mathrm{H}-4 / \mathrm{H}-5 / \mathrm{H}-6 / \mathrm{H}-7 / \mathrm{H}-8 / \mathrm{H}-9 / \mathrm{H}-10$ also confirmed this structure. The trans orientation at C-4 and C-5 was determined by the NOESY correlations of $\mathrm{H}-4$ with $\mathrm{H}-6$ and $\mathrm{H}-7$. The absolute configuration of 2 at C-9 was determined by comparing its NMR data with that of $(4 E, 6 R, 9 R)-6,9-$ dihydroxydec-4-enoic acid, which has a highly similar structure and is isolated from fungus Cylindrocarpon $\mathrm{sp}$. and by comparing NMR data with that of 8-Oacetylmultiplolide A isolated in this research. ${ }^{12,13}$ The configuration of C-7 was determined based on its derivative (7), whose configuration was determined by the NOESY correlation between $\mathrm{H}-7$ and $\mathrm{H}-9$ in a cyclic ketal structure. Thus, the structure of compound 2 was determined as diaporthsin B.

Compound 3 was obtained as a colorless oil; its molecular formula was determined to be $\mathrm{C}_{12} \mathrm{H}_{22} \mathrm{O}_{4}$ by the analysis of its HRESI-MS spectrum and NMR data (Table 1). A detailed analysis of its NMR data revealed that its structure was highly similar to that of compound 2 isolated from this strain except

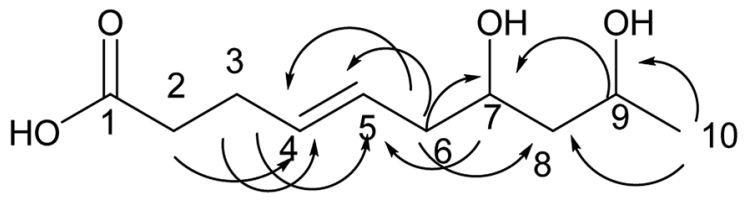

Fig. 3 The key HMBC correlations of compound 2.

Table $1{ }^{13} \mathrm{C}$ NMR and ${ }^{1} \mathrm{H}$ NMR data of compounds $1-3$

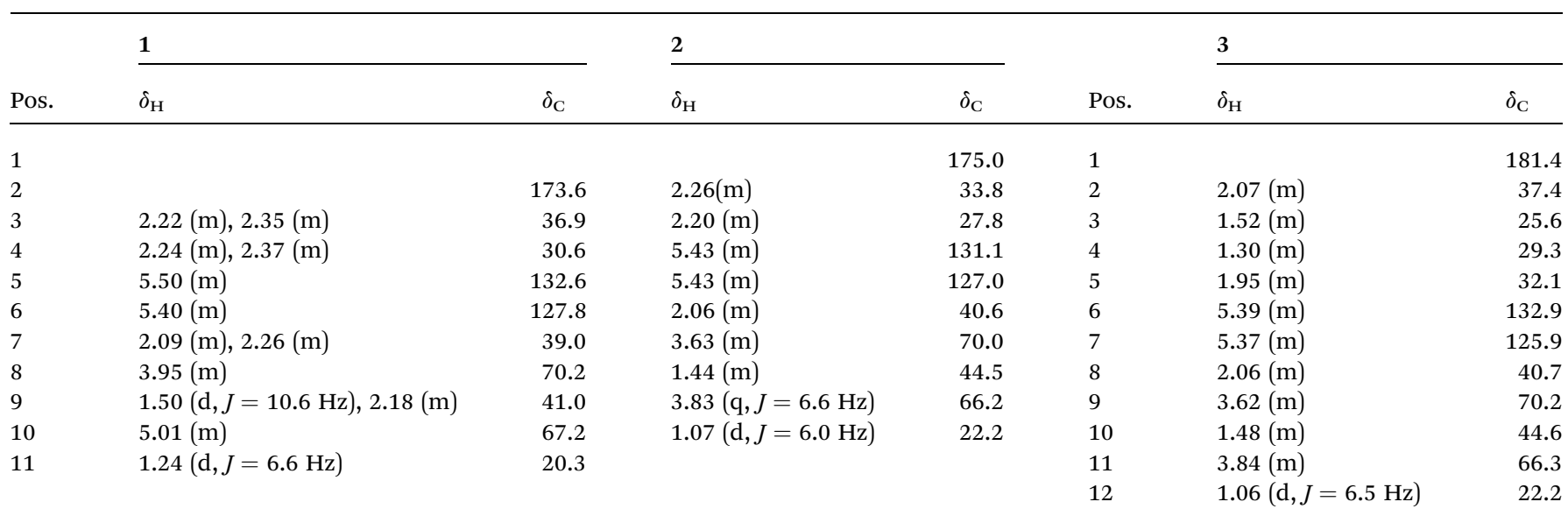




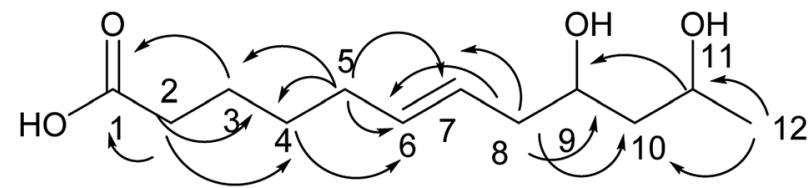

Fig. 4 The key HMBC correlations of compound 3.

that two more $\mathrm{CH}_{2}$ groups were observed in the NMR spectrum of 3 than that in the NMR spectrum of 2 . The structure of compound 3 was determined from the HMBC correlations from $\mathrm{H}-2$ to $\mathrm{C}-3, \mathrm{C}-4 ; \mathrm{H}-2, \mathrm{H}-3$ to $\mathrm{C}-1 ; \mathrm{H}-5$ to C-3, C-4, C-6, C-7; H-8 to C-6, C-7, C-9, C-10; H-11 to C-9; H-12 to C-10, C-11 (Fig. 4). The COSY correlations of $\mathrm{H}-2 / \mathrm{H}-3 / \mathrm{H}-4 / \mathrm{H}-5 / \mathrm{H}-6 / \mathrm{H}-7 / \mathrm{H}-8 / \mathrm{H}-9 / \mathrm{H}-10 / \mathrm{H}-$ $11 / \mathrm{H}-12$ also confirmed this structure. The configurations of 3 at C-9 and C-11 and the trans orientation at C- 6 and C-7 were determined by comparing the NMR data with that of 2 . On the basis of these data, the structure of compound 3 was determined as diaporthsin C. Diaporthsin $\mathrm{C}$ was the only $\mathrm{C}_{12}$-polyketone obtained in this research.

Compound 4 was obtained as a colorless oil; its molecular formula was determined to be $\mathrm{C}_{14} \mathrm{H}_{26} \mathrm{O}_{5}$ by the analysis of its HRESI-MS spectrum and NMR data (Table 2). Detailed analysis of its NMR data revealed that its structure was highly similar to that of compound 2 isolated from this strain except for one more 2,3-butanediol group in compound 4. The 2,3-butanediol group was elucidated by the COSY correlations of $\mathrm{H}-1^{\prime} / \mathrm{H}-2^{\prime} / \mathrm{H}-$ $3^{\prime} / \mathrm{H}-4^{\prime}$, and the connection to $\mathrm{C}-1$ was determined by the HMBC correlation from $\mathrm{H}-2^{\prime}$ to $\mathrm{C}-1$ (Fig. 5). The structure of compound 4 was determined by the HMBC correlations from $\mathrm{H}-3$ to $\mathrm{C}-1, \mathrm{C}-$ 2, C-4, C-5; H-6 to C-4, C-5, C-7; H-8 to C-6, C-7; H-9 to C-7, C-8; $\mathrm{H}-10$ to C-8, C-9 (Fig. 5). The COSY correlations of $\mathrm{H}-2 / \mathrm{H}-3 / \mathrm{H}-4 /$ $\mathrm{H}-5 / \mathrm{H}-6 / \mathrm{H}-7 / \mathrm{H}-8 / \mathrm{H}-9 / \mathrm{H}-10$ also confirmed this structure. The configurations of 4 at C-7 and C-9 and the trans orientation at C4 and C- 5 were determined by comparing the NMR data with that of 2 and biogenesis. The configuration of 2,3-butanediol was determined as $2^{\prime} S, 3^{\prime} R$ by the diastereoisomers observed in

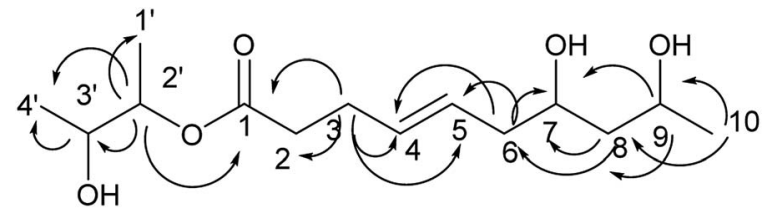

Fig. 5 The key HMBC correlations of compound 4.

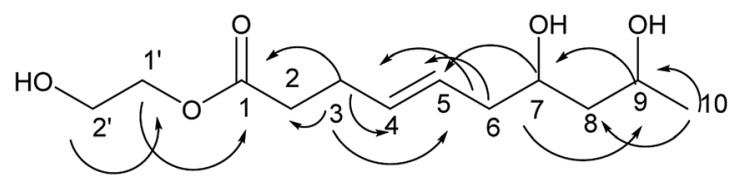

Fig. 6 The key HMBC correlations of compound 5 .

the NMR data of compound 4. On the basis of these data, the structure of compound 4 was determined as diaporthsin D.

Compound 5 was obtained as a colorless oil and its molecular formula was determined to be $\mathrm{C}_{12} \mathrm{H}_{22} \mathrm{O}_{5}$ based on the analysis of its HRESI-MS spectrum and NMR data (Table 2). Detailed analysis of its NMR data revealed that its structure was highly similar to that of compound 2 isolated in this study except for one more glycol in compound 5 . The two $\mathrm{OH}$ groups connected to $\mathrm{C}-\mathbf{1}^{\prime}$ and C-2 ${ }^{\prime}$ were determined by the HMBC correlation from $\mathrm{H}-2^{\prime}$ to $\mathrm{C}-1^{\prime}$ (Fig. 6) and the correlation of $\mathrm{H}-1^{\prime} / \mathrm{H}-2^{\prime}$ in the COSY spectrum, which suggested the presence of one glycol group. The glycol connected to $\mathrm{C}-1$ was verified by the $\mathrm{HMBC}$ correlations from $\mathrm{H}$ $1^{\prime}$ to $\mathrm{C}-1$ (Fig. 6). The structure of compound 5 was determined by the HMBC correlations from H-3 to C-1, C-2, C-4, C-5; H-6 to C-4, C-5; H-7 to C-5, C-9; H-9 to C-7; H-10 to C-8, C-9 (Fig. 6). The configurations of 5 at C-7 and C-9 and the trans orientation at C-4 and C-5 were determined by comparing its NMR data with that of 2. On the basis of these data, the structure of compound 5 was determined and named diaporthsin $\mathrm{E}$.

Compound 6 was obtained as a colorless oil; its molecular formula was determined to be $\mathrm{C}_{13} \mathrm{H}_{20} \mathrm{O}_{6}$ by the analysis of its

Table $2{ }^{13} \mathrm{C}$ NMR and ${ }^{1} \mathrm{H}$ NMR data of compounds 4-6

\begin{tabular}{|c|c|c|c|c|c|c|}
\hline Pos. & \multicolumn{2}{|l|}{4} & \multicolumn{2}{|l|}{5} & \multicolumn{2}{|l|}{6} \\
\hline 2 & $2.30(\mathrm{~m})$ & 33.9 & $2.32(\mathrm{t}, J=7.5 \mathrm{~Hz})$ & 33.6 & $2.34(\mathrm{~m})$ & 27.3 \\
\hline 3 & $2.23(\mathrm{~m})$ & 27.7 & $2.24(\mathrm{~m})$ & 27.6 & $1.79(\mathrm{~m}), 1.98(\mathrm{~m})$ & 22.5 \\
\hline 4 & $5.42(\mathrm{~m})$ & 130.8 & $5.44(\mathrm{~m})$ & 130.8 & $3.80(\mathrm{~m})$ & 74.8 \\
\hline 7 & $3.63(\mathrm{~m})$ & 70.0 & $3.63(\mathrm{~m})$ & 69.9 & $4.86(\mathrm{~d}, J=6.0 \mathrm{~Hz})$ & 76.0 \\
\hline 8 & $1.44(\mathrm{~m})$ & 44.5 & $1.45(\mathrm{~m})$ & 44.6 & $2.06(\mathrm{~m}), 2.20(\mathrm{~m})$ & 39.0 \\
\hline 9 & $3.84(\mathrm{q}, J=6.0 \mathrm{~Hz})$ & 66.2 & $3.83(\mathrm{q}, J=6.0 \mathrm{~Hz})$ & 66.1 & $5.10(\mathrm{~m})$ & 66.7 \\
\hline 10 & $1.06(\mathrm{~d}, J=6.0 \mathrm{~Hz})$ & 22.2 & $1.07(\mathrm{~d}, J=6.5 \mathrm{~Hz})$ & 22.2 & $1.12(\mathrm{~d}, J=5.5 \mathrm{~Hz})$ & 18.7 \\
\hline $1^{\prime}$ & $1.08(\mathrm{~d}, J=6.5 \mathrm{~Hz})$ & 14.7 & $4.03(\mathrm{t}, J=5.0 \mathrm{~Hz})$ & 65.5 & & 170.7 \\
\hline $2^{\prime}$ & $4.67(\mathrm{~m})$ & 74.2 & $3.62(\mathrm{t}, J=5.0 \mathrm{~Hz})$ & 59.6 & $2.20(\mathrm{~s})$ & 19.3 \\
\hline
\end{tabular}




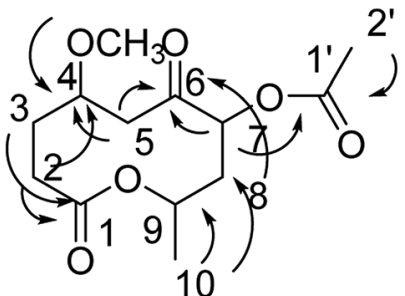

Fig. 7 The key HMBC correlations of compound 6 .

HRESI-MS spectrum and NMR data (Table 2). The NMR spectra of 6 indicated two methyls, four methylenes, and three methines as well as three carbonyl groups and one methoxyl group (Table 2). The presence of acetyl signal was determined by the HMBC correlations from $\mathrm{H}-2^{\prime}$ to $\mathrm{C}-1^{\prime}$; the acetyl connected to C-7 was determined by the HMBC correlations from $\mathrm{H}-7$ to $\mathrm{C}-\mathrm{1}^{\prime}$ (Fig. 7). The methoxyl group connected to $\mathrm{C}-4$ was determined by the HMBC correlations from $\mathrm{OCH}_{3}$ to C-4 (Fig. 7) and the COSY correlations of $\mathrm{H}-2 / \mathrm{H}-3 / \mathrm{H}-4 / \mathrm{H}-5$. Furthermore, according to the HMBC correlations from $\mathrm{H}-5, \mathrm{H}-7, \mathrm{H}-8$ to $\mathrm{C}-6$; $\mathrm{H}-2$ to $\mathrm{C}-4$; $\mathrm{H}-2, \mathrm{H}-3$ to $\mathrm{C}-1$; $\mathrm{H}-10$ to $\mathrm{C}-8, \mathrm{C}-9$, these data show the positions of ketone carbonyl and two hydroxyls at C-6, C-7, and C-9 (Fig. 7). The connection of C-1 and C-9 was confirmed by ${ }^{1} \mathrm{H}-$ NMR of H-9 at $\delta 5.10$. The configurations of 6 at C-7 and C-9 were determined by comparing the NMR data with those of compounds 2-5 and biogenesis. The NOESY correlations of $\mathrm{H}-7$ / $\mathrm{H}-9$ also confirmed this elucidation. The configuration of C-4 of 6 was determined as $S$ by comparing NMR and optical rotation with those of its demethoxy product $8 \alpha$-acetoxy- $5 \alpha$-hydroxy-7oxodecan-10-olide isolated from Phomopsis sp. ${ }^{14}$ On the basis of these data, the structure of compound $\mathbf{6}$ was determined and termed diaporthsin $\mathrm{F}$.

Compound 7 was obtained as a colorless oil; its molecular formula was determined to be $\mathrm{C}_{12} \mathrm{H}_{20} \mathrm{O}_{4}$ by the analysis of its HRESI-MS spectrum and NMR data (Table 3). A detailed analysis of its NMR data revealed that its structure was highly similar to that of compound 2 except for a cyclic ketal structure in compound 7 . The cyclic ketal structure was determined by the COSY correlations of $\mathrm{H}-1^{\prime} / \mathrm{H}-2^{\prime}$ and the HMBC correlations

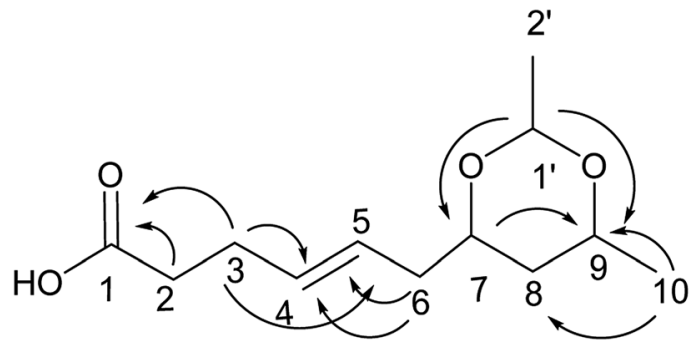

Fig. 8 The key HMBC correlations of compound 7 .

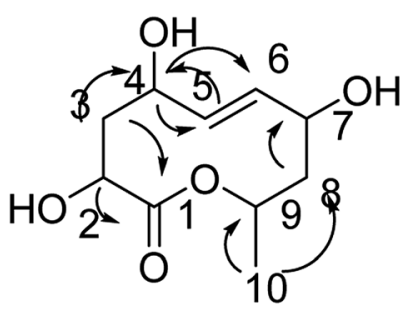

Fig. 9 The key HMBC correlations of compound 8

from $\mathrm{H}-1^{\prime}$ to $\mathrm{C}-7$ and $\mathrm{C}-9$ (Fig. 8). The structure of compound 7 was confirmed by the HMBC correlations from $\mathrm{H}-3$ to $\mathrm{C}-1, \mathrm{C}-4$, C-5; H-6 to C-4, C-5; H-7 to C-9; H-10 to C-8, C-9 (Fig. 8) and the COSY correlations of $\mathrm{H}-9 / \mathrm{H}-10 ; \mathrm{H}-2 / \mathrm{H}-3 / \mathrm{H}-4 / \mathrm{H}-5 / \mathrm{H}-6$. The relative configurations of $\mathrm{H}-7$ and $\mathrm{H}-9$ were determined by the NOESY correlation between $\mathrm{H}-7$ and $\mathrm{H}-9$. The absolute configuration of 7 and the trans orientation at C-4 and C-5 were determined by comparing its NMR data with those of compounds 2-6 and the biogenesis. On the basis of these data, the structure of compound 7 was determined as diaporthsin G.

Compound 8 was obtained as white crystals; its molecular formula was determined to be $\mathrm{C}_{10} \mathrm{H}_{16} \mathrm{O}_{5}$ by the analysis of its HRESI-MS spectrum and NMR data (Table 3). The NMR spectra of 8 indicated one methyl group, four hydroxylated methines, two methylenes, two methines and one carbonyl group (Table $3)$. According to the HMBC correlation from $\mathrm{H}-2, \mathrm{H}-3$ to $\mathrm{C}-1 ; \mathrm{H}-3$ to C-4; H-4 to C-5, C-6; H-8 to C-7; H-10 to C-8, C-9 (Fig. 9) and

Table $3{ }^{13} \mathrm{C}$ NMR and ${ }^{1} \mathrm{H}$ NMR data of compounds 7-9

\begin{tabular}{|c|c|c|c|c|c|c|c|}
\hline \multirow[b]{2}{*}{ Pos. } & \multicolumn{2}{|l|}{7} & \multicolumn{2}{|l|}{8} & \multirow[b]{2}{*}{ Pos. } & \multicolumn{2}{|l|}{9} \\
\hline & $\delta_{\mathrm{H}}$ & $\delta_{\mathrm{C}}$ & $\delta_{\mathrm{H}}$ & $\delta_{\mathrm{C}}$ & & $\delta_{\mathrm{H}}$ & $\delta_{\mathrm{C}}$ \\
\hline 1 & & 173.6 & & 172.2 & 1 & & 173.6 \\
\hline 2 & $2.33(\mathrm{~m})$ & 33.4 & $4.52(\mathrm{~m})$ & 68.1 & 2 & $2.31(\mathrm{~m})$ & 34.0 \\
\hline 3 & $2.27(\mathrm{~m})$ & 27.8 & $2.22(\mathrm{~m}), 2.84(\mathrm{~m})$ & 45.6 & 3 & $2.26(\mathrm{~m})$ & 28.0 \\
\hline 4 & $5.53(\mathrm{~m})$ & 131.1 & $4.52(\mathrm{~m})$ & 70.3 & 4 & $5.46(\mathrm{~m})$ & 132.4 \\
\hline 5 & $5.51(\mathrm{~m})$ & 126.5 & $5.60(\mathrm{~m})$ & 129.7 & 5 & $5.40(\mathrm{~m})$ & 127.0 \\
\hline 6 & $2.06(\mathrm{~m}), 2.18(\mathrm{~m})$ & 39.0 & $5.50(\mathrm{~m})$ & 134.7 & 6 & $2.06(\mathrm{~m}), 2.12(\mathrm{~m})$ & 41.3 \\
\hline 7 & $3.56(\mathrm{~m})$ & 75.7 & $3.78(\mathrm{~m})$ & 73.8 & 7 & $3.76(\mathrm{~m})$ & 72.0 \\
\hline 8 & $1.06(\mathrm{~m}), 1.54(\mathrm{~m})$ & 37.9 & $1.03(\mathrm{~m}), 2.43(\mathrm{~m})$ & 34.9 & 8 & $1.42(\mathrm{~m}), 1.49(\mathrm{~m})$ & 44.3 \\
\hline 9 & $3.70(\mathrm{~m})$ & 71.8 & $4.95(\mathrm{~m})$ & 70.1 & 9 & $3.96(\mathrm{~m})$ & 68.8 \\
\hline 10 & $1.13(\mathrm{~d}, J=6.5 \mathrm{~Hz})$ & 21.0 & $1.20(\mathrm{~d}, J=6.8 \mathrm{~Hz})$ & 17.5 & 10 & $1.13(\mathrm{~d}, J=6.2 \mathrm{~Hz})$ & 24.0 \\
\hline $1^{\prime}$ & $4.66(\mathrm{q}, J=5.0 \mathrm{~Hz})$ & 98.0 & & & $\mathrm{OCH}_{3}$ & $3.60(\mathrm{~s})$ & 51.6 \\
\hline $2^{\prime}$ & $1.20(\mathrm{~d}, J=5.0 \mathrm{~Hz})$ & 20.6 & & & & & \\
\hline
\end{tabular}




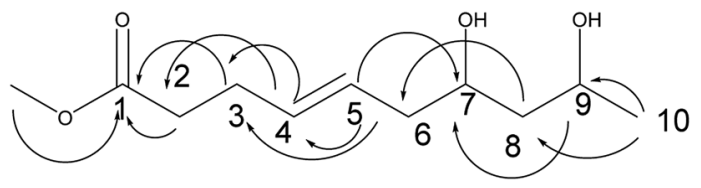

Fig. 10 The key HMBC correlations of compound 9.

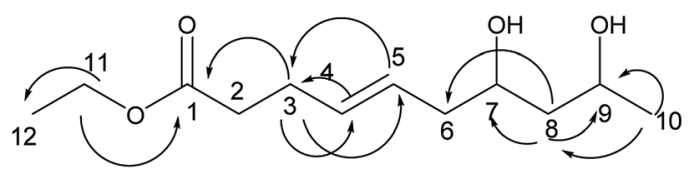

Fig. 11 The key HMBC correlations of compound 10 .

COSY correlations of $\mathrm{H}-2 / \mathrm{H}-3 / \mathrm{H}-4 / \mathrm{H}-5 / \mathrm{H}-6 / \mathrm{H}-7 / \mathrm{H}-8 / \mathrm{H}-9 / \mathrm{H}-10$, these data suggest the four $\mathrm{OH}$ groups connected to C-2, C-4, C-7, and C-9. The connection between C-1 and C-9 was confirmed by ${ }^{1} \mathrm{H}-\mathrm{NMR}$ of $\mathrm{H}-9$ at $\delta 4.95$. The absolute configurations of C-7 and C-9 were determined by comparing the NMR data with those of compounds $2-7$ and biogenesis. The trans orientation at C-5 and C- 6 was determined by NOESY correlation between $\mathrm{H}-5$ and $\mathrm{H}-7$. The configurations of C-2, C-4, C-7 and C-9 were determined by comparing the NMR data with those of compounds 2-7 and the biogenesis; the NOESY correlations of $\mathrm{H}-2$ and $\mathrm{H}-4 ; \mathrm{H}-7$ and $\mathrm{H}-10 ; \mathrm{H}-9$ and $\mathrm{H}-10$ also confirmed this elucidation. Thus, the structure of compound 8 was determined as diaporthsin $\mathrm{H}$.

Compound 9 was obtained as a colorless oil. The molecular formula of 9 was established as $\mathrm{C}_{11} \mathrm{H}_{20} \mathrm{O}_{4}$ by the HRESI-MS and NMR data (Table 3). The ${ }^{1} \mathrm{H}$ NMR and ${ }^{13} \mathrm{C}$ NMR data showed that 9 exhibited a similar skeleton to that of compound 2 except for one more methoxyl in compound $\mathbf{9}$. The structure of compound 9 was determined by the $\mathrm{HMBC}$ correlations from $\mathrm{H}-2, \mathrm{H}-3$ to $\mathrm{C}-1, \mathrm{H}-4$ to $\mathrm{C}-2, \mathrm{C}-3$; H-5 to C-3, C4; $\mathrm{H}-9$ to $\mathrm{C}-7, \mathrm{H}-10$ to $\mathrm{C}-8, \mathrm{C}-9$; $\mathrm{OCH}_{3}$ to $\mathrm{C}-1$ (Fig. 10). The absolute configurations of C-7 and C-9 and the trans orientation at C-4 and C- 5 were determined by comparing the NMR

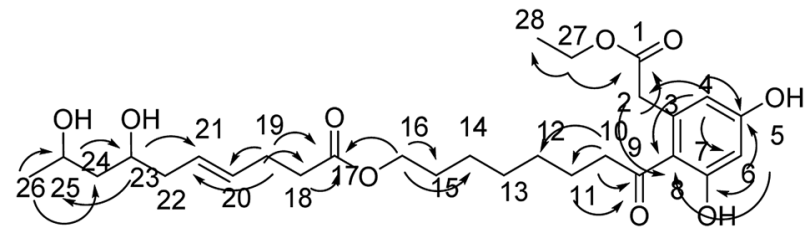

Fig. 12 The key HMBC correlations of compound 11 .

data with those of compounds 2-7 and biogenesis. Thus, the structure of compound $\mathbf{9}$ was determined as diaporthsin I.

Compound 10 was obtained as a colorless oil. The molecular formula of $\mathbf{1 0}$ was established as $\mathrm{C}_{12} \mathrm{H}_{22} \mathrm{O}_{4}$ by the HRESI-MS and NMR data (Table 3). A detailed analysis of its NMR data revealed that its structure was highly similar to that of compound 2 isolated in this study except for one more alcohol in compound 10. The oxethyl group was elucidated by the COSY correlations of $\mathrm{H}-11 / \mathrm{H}-12$ and its connection to $\mathrm{C}-1$ was determined by the HMBC correlations from $\mathrm{H}-11$ to $\mathrm{C}-1$ (Fig. 11). The structure of compound $\mathbf{1 0}$ was determined by the HMBC correlations from $\mathrm{H}-3$ to C-1, C-4, C-5; H-4 to C-3; H-10 to C-8, C9 (Fig. 11) and the COSY correlations of $\mathrm{H}-2 / \mathrm{H}-3 / \mathrm{H}-4 / \mathrm{H}-5 / \mathrm{H}-6 / \mathrm{H}-$ $7 / \mathrm{H}-8 / \mathrm{H}-9 / \mathrm{H}-10$. Moreover, the absolute configurations of C-7 and $\mathrm{C}-9$ and the trans orientation at C-4 and C-5 were determined by comparing the NMR data with those of new compounds. Thus, the structure of compound $\mathbf{1 0}$ was determined as diaporthsin $\mathrm{J}$.

Compound $\mathbf{1 1}$ was obtained as an orange-red oil; its molecular formula was determined to be $\mathrm{C}_{28} \mathrm{H}_{42} \mathrm{O}_{9}$ by the analysis of its HRESI-MS spectrum and NMR data (Table 4). In ${ }^{1} \mathrm{H}$ NMR spectrum, two aromatic protons at $\delta 6.22(1 \mathrm{H}, \mathrm{d}, J=2.0 \mathrm{~Hz})$ and $6.28(1 \mathrm{H}, \mathrm{d}, J=2.0 \mathrm{~Hz})$ were observed; the ${ }^{13} \mathrm{C}$ NMR spectrum showed six carbon signals at $\delta 101.4,110.3,120.0,135.6,158.4$, and 159.9, suggesting the existence of four substituted benzene species in compound 11 (Table 4). The structure of the cytosporone fraction of this compound was confirmed by the HMBC correlations from $\mathrm{H}-27$ to C-1, C-28; H-4 to C-2, C-5, and C-6; H-6 to C-5, C-7, C-8; H-2 to C-8; H-10, H-11 to C-9; H-10 to C-11, C-12; H-16 to C-14, C-15, C-17 (Fig. 12). The structure of the

Table $4{ }^{13} \mathrm{C}$ NMR and ${ }^{1} \mathrm{H}$ NMR data of compounds $10-11$

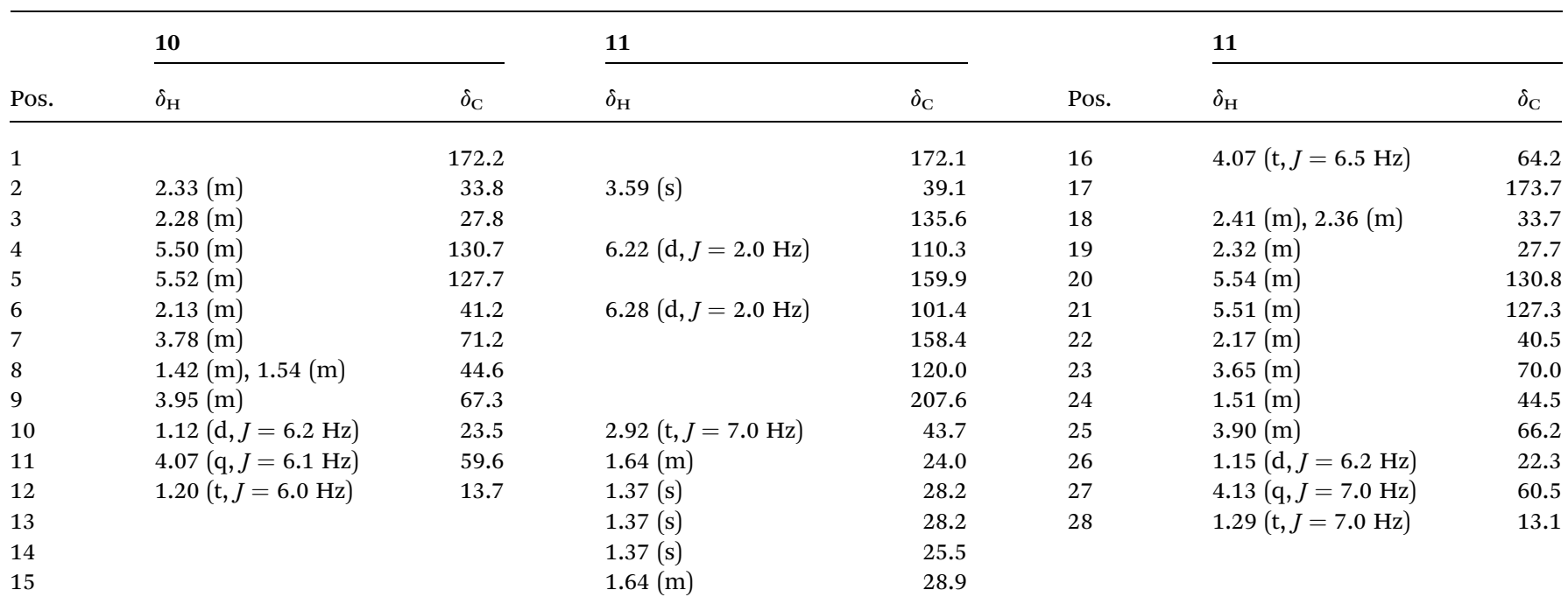


multiplolide fraction of this compound was confirmed by the HMBC correlations from $\mathrm{H}-18, \mathrm{H}-19$ to C-17; H-19 to C-20, C-21; H-23 to C-21, C-25; H-26 to C-24, C-25; H-25 to C-23. According to these data, the structure of compound 11 was obtained by esterification reaction of compound 2 and dothiorelone C. ${ }^{\mathbf{1 5}}$ Thus, the structure of compound $\mathbf{1 1}$ was determined as diaporthsin $\mathrm{K}$.

Other known compounds were isolated and determined as (4E)-6,7,9-trihydroxydec-4-enoic acid, ${ }^{12}$ multiplolide $\mathrm{A}^{12}$ 8-Oacetylmultiplolide $\mathrm{A},{ }^{12}$ and phomopsisporone $\mathrm{A} .{ }^{16}$ Most of the new polyketones were esterified products of 2 . We tested the possibility of artificial reaction of compound $\mathbf{1}$ in solvents of methanol and ethanol at $76{ }^{\circ} \mathrm{C}$ for 10 hours, but the reaction was unsuccessful. Thus, we infer that esterification should occur in fungal biotransformation.

Cardiovascular disease (CVD), which is currently the leading cause of death in developed countries, is expected to become a predominant health problem worldwide. Atherosclerosis, a progressively evolving disease characterized by the accumulation of lipids and fibrous elements in large arteries, constitutes the single most important contributor to this growing burden of CVD. ${ }^{17}$ Currently, treatment of atherosclerosis is aimed at reducing blood cholesterol and triglyceride contents. ${ }^{18}$ Decarestrictines, which are novel 10-membered lactones, are produced by different strains of Penicillium. Some of them have inhibitory effects on the cholesterol biosynthesis. ${ }^{19}$ Our isolated polyketones belonged to the skeleton of decarestrictine; thus, the antihyperlipidemic activities of these compounds 1, 2, 3, 5, 8, 10, (4E)-6,7,9-trihydroxydec-4-enoic acid (THEA), 8-O-acetylmultiplolide A, multiplolide A, and phomopsisporone A were investigated. Compound 5, (4E)-6,7,9-trihydroxydec-4-enoic acid, 8-O-acetylmultiplolide A, and phomopsisporone A displayed lipid lowering effects on triglycerides (TG) in steatotic L02 cells with inhibition ratios of $26 \%, 21 \%, 24 \%$, and $16 \%$, respectively, at a concentration of $5 \mu \mathrm{g} \mathrm{mL} \mathrm{m}^{-1}$. Lovastatin was used as a positive control with inhibition ratio of $31.80 \%$ at concentration of $5 \mu \mathrm{g} \mathrm{mL} \mathrm{m}^{-1}$ 8-O-acetylmultiplolide A exhibited better lipid lowering effect than multiplolide $A$, whereas compound 5 and (4E)-6,7,9-trihydroxydec-4-enoic acid exhibited more activities than compound 2 in antihyperlipidemic assay (Table 5). The structural difference between 8-O-acetylmultiplolide A and multiplolide A was one more acetyl group at C-8 in

Table 5 Antihyperlipidemic activities of these compounds at concentration of $5 \mu \mathrm{g} \mathrm{mL}^{-1}$

\begin{tabular}{lll}
\hline Sample & $\begin{array}{l}\text { TG concentration } \\
\left(\mathrm{mmol} \mathrm{g}^{-1}\right)\end{array}$ & Inhibition ratio \\
\hline $\mathbf{5}$ & 0.307 & $26 \%$ \\
THEA & 0.326 & $21 \%$ \\
8-O-Acetylmultiplolide & 0.312 & $24 \%$ \\
A & & \\
Phomopsisporone A & 0.332 & $16 \%$ \\
Lovastatin & 0.283 & $31 \%$ \\
Other compounds & & $<10 \%$ \\
Control & 0.415 & \\
Normal & 0.015 &
\end{tabular}

8-O-acetylmultiplolide A than that in multiplolide A; the other differences observed in this study include one more glycol ester in 5 than that in 2 and one more hydroxyl at C-6 in (4E)-6,7,9trihydroxydec-4-enoic acid than that in 2 . Compound 2 and multiplolide A showed no clear antihyperlipidemic activity with inhibition ratios of $<5 \%$ at the concentration of $5 \mu \mathrm{g} \mathrm{mL}$ Hence, the acetyl at C-8 can increase the antihyperlipidemic activity of multiplolide $\mathrm{A}$, and the glycol ester and hydroxyl at $\mathrm{C}$ 6 can also increase the corresponding activity of diaporthsin B. These compounds were evaluated for their cytotoxicity, but no activity was observed with $\mathrm{IC}_{50}>100 \mu \mathrm{M}$.

\section{Conclusions}

Eleven new polyketones named diaporthsins A-K (1-11) were isolated from the fermentation of Diaporthe sp. JC-J7. Compound 11 featured an unusual acyclic polyketone-phenolic polyketone hybrid structure that integrates the characteristics of different fungal metabolites (cytosporone and multiplolide). Compound 3 was the only $\mathrm{C}_{12}$-polyketone obtained in this study. These polyketones showed significant inhibitory activity on triglycerides (TG) in steatotic L-02 cells, which exhibited potential antihyperlipidemic activities in corresponding drug research.

\section{Experimental}

\section{General experimental procedures}

Silica gel (200-300 mesh, Qingdao Marine Chemical Group Co., Qingdao, China), LiChroprep RP-18 (40-63 mm; Merck, Darmstadt, Germany) and Sephadex LH-20 (GE Healthcare Co., Buckinghamshire, UK) were used for column chromatography. 1D and 2D NMR spectra were obtained on a Bruker AVANCE 400, 500, 600 MHz NMR instrument (Bruker, Karlsruhe, Germany). MS spectra were recorded with Agilent G3250AA (Agilent, Santa Clara, USA) and AutoSpec Premier P776 spectrometers (Waters, Milford, USA). ORs were obtained on a Jasco P-1020 polarimeter.

\section{Fungal material and fermentation}

The endophytic fungus JC-J7 was isolated using potato dextrose agar medium (PDA) (peeled and cut potato $200 \mathrm{~g} \mathrm{~L}^{-1}$, glucose $20 \mathrm{~g} \mathrm{~L}^{-1}$, agar $15 \mathrm{~g} \mathrm{~L}^{-1}$ ) from stems of Dendrobium nobile isolated from Honghe of Yunnan province and identified as Diaporthe sp. JC-J7 by ITS gene sequencing. The fungus has been preserved at the School of Chemical Science and Technology, Yunnan University, China. The pure strain was stored in 50\% glycerol at $-80{ }^{\circ} \mathrm{C}$. Diaporthe sp. JC-J7 was maintained in PDA medium. Small agar plugs (approximately $5 \mathrm{~mm} \times 5 \mathrm{~mm}$ ) of the fungus were cultured in $0.5 \mathrm{~L}$ Erlenmeyer flasks containing $100 \mathrm{~mL}$ of potato dextrose broth (PDB, potato infusion of $200 \mathrm{~g}$ fresh potato, dextrose $15 \mathrm{~g}$, distilled water $1.0 \mathrm{~L}, \mathrm{pH} \mathrm{7.0)}$ at $130 \mathrm{rpm}$ and $28^{\circ} \mathrm{C}$ for 3 days. Each $20-25 \mathrm{~mL}$ of seed culture was transferred into a $1.0 \mathrm{~L}$ Erlenmeyer flask containing $250 \mathrm{~mL}$ of PDB and incubated at $130 \mathrm{rpm}$ and $28{ }^{\circ} \mathrm{C}$ for 7 days. 


\section{Extraction and isolation of new compounds}

The production culture $(50 \mathrm{~L})$ was centrifuged to separate the mycelia from the supernatant. The extracts of the fermentation broth and the mycelia were combined after TLC analysis to yield a crude extract $(30 \mathrm{~g})$. The residue was first subjected to column chromatography (CC) (silica gel, $\mathrm{CHCl}_{3} / \mathrm{MeOH} 100: 0,50: 1$, $30: 1,10: 1$ and $3: 1(\mathrm{v} / \mathrm{v}))$ to afford fractions $1-5$, respectively.

Fr. 1 was fractionated by silica gel chromatography eluted with petroleum ether/EtOAc $(80: 1,40: 1,20: 1,10: 1,3: 1$, $1: 1)$ to give six subfractions (Fr. $1.1-$ Fr. 1.6). Then, Fr. 1.3 was eluted using Sephadex LH-20 (methanol) to obtain three subfractions (Fr. 1.3.1-Fr. 1.3.3). Fr. 1.3.1 was eluted through Sephadex LH-20 (methanol) to afford compound 1 (27 mg).

Fr. 3 was fractionated by silica gel $\mathrm{CC}$ eluted with $\mathrm{CHCl}_{3} /$ $\mathrm{MeOH}(50: 1,20: 1,5: 1)$ to give five subfractions (Fr. 3.1-Fr. 3.5). Fr. 3.3 was further subjected to CC (silica gel, petroleum ether/acetone $3: 1$ ) and Sephadex LH-20 (methanol) to afford compound 2 ( $2 \mathrm{mg}$ ) and compound 3 ( $4 \mathrm{mg})$. Fr. 3.2 was further separated by CC eluted with petroleum ether/EtOAc $(8: 1)$ to give compound 6 ( $3 \mathrm{mg})$. Fr. 3.1 was fractionated by column chromatography on Lichroprep RP-18 eluted with $\mathrm{MeOH}-\mathrm{H}_{2} \mathrm{O}$ (20-100\%) into four subfractions (Fr. 3.1.1 - Fr. 3.1.4). Fr. 3.1.1 was eluted using Sephadex LH-20 (methanol) to afford compound 4 (5 mg) and compound 5 (7 mg). Fr. 3.1.2 was further purified using CC (silica gel, petroleum ether/EtOAc $6: 1$ ) and SephadexLH-20 (methanol) to yield compounds 7 (3 $\mathrm{mg}), \mathbf{9}(6.4 \mathrm{mg})$ and 10 (4 mg). Fr. 4 was further subjected to CC (silica gel, $\mathrm{CHCl}_{3} / \mathrm{MeOH} 20: 1,10: 1,5: 1$ ) to afford Fr. 4.1-Fr. 4.4. Compounds $8(12 \mathrm{mg})$ and $11(10 \mathrm{mg})$ were obtained from Fr. 4.2 by Sephadex LH-20 (methanol).

Diaporthsin A (1): colorless oil; $[\alpha]_{\mathrm{D}}^{23} 8.95$ (c 0.27, $\mathrm{CHCl}_{3}$ ); IR $(\mathrm{KBr}) \nu_{\max } 3438,2955,2852,1636,1460 \mathrm{~cm}^{-1} .{ }^{1} \mathrm{H}$ NMR $(600$ $\mathrm{MHz}$ ) and ${ }^{13} \mathrm{C}$ NMR (150 MHz) in $\mathrm{CDCl}_{3}$, see Table 1 . HR-ESIMS $m / z$ 185.1171 $[\mathrm{M}+\mathrm{H}]^{+}$(calcd for $\mathrm{C}_{10} \mathrm{H}_{17} \mathrm{O}_{3}$ 185.1178).

Diaporthsin B (2): colorless oil; $[\alpha]_{\mathrm{D}}^{23} 30.15$ (c 0.1, MeOH); IR (KBr) $\nu_{\max } 3428,2925,1637,1438 \mathrm{~cm}^{-1} \cdot{ }^{1} \mathrm{H}$ NMR $(600 \mathrm{MHz})$ and ${ }^{13} \mathrm{C}$ NMR (150 MHz) in MeOD, see Table 1. HR-ESIMS $\mathrm{m} / \mathrm{z}$ 225.1098 [M + Na $]^{+}$(calcd for $\mathrm{C}_{10} \mathrm{H}_{18} \mathrm{O}_{4} \mathrm{Na} 225.1103$ ).

Diaporthsin C (3): colorless oil; $[\alpha]_{\mathrm{D}}^{23} 341.93$ (c 0.01, MeOH); IR (KBr) $\nu_{\max } 3431,2963,1624,1414 \mathrm{~cm}^{-1} \cdot{ }^{1} \mathrm{H}$ NMR (600 MHz) and ${ }^{13} \mathrm{C}$ NMR $(150 \mathrm{MHz})$ in MeOD, see Table 1 . HR-ESIMS $m / z$ 253.1410 $[\mathrm{M}+\mathrm{Na}]^{+}$(calcd for $\mathrm{C}_{12} \mathrm{H}_{22} \mathrm{O}_{4} \mathrm{Na} 253.1416$ ).

Diaporthsin D (4): colorless oil; $[\alpha]_{\mathrm{D}}^{23} 79.95$ (c 0.044, MeOH); IR (KBr) $\nu_{\max } 3393,2969,1724,1437 \mathrm{~cm}^{-1} \cdot{ }^{1} \mathrm{H}$ NMR $(500 \mathrm{MHz})$ and ${ }^{13} \mathrm{C}$ NMR (125 MHz) in MeOD, see Table 2. HR-ESIMS $\mathrm{m} / \mathrm{z}$ 297.1672 [M $+\mathrm{Na}]^{+}$(calcd for $\mathrm{C}_{14} \mathrm{H}_{26} \mathrm{O}_{5} \mathrm{Na} 297.1678$ ).

Diaporthsin E (5): colorless oil; $[\alpha]_{\mathrm{D}}^{23} 305.63$ (c 0.011, MeOH); IR (KBr) $\nu_{\max } 3423,2923,1724,1636,1384 \mathrm{~cm}^{-1} .{ }^{1} \mathrm{H}$ NMR (500 $\mathrm{MHz}$ ) and ${ }^{13} \mathrm{C}$ NMR (125 MHz) in MeOD, see Table 2. HR-ESIMS $m / z 247.1542[\mathrm{M}+\mathrm{H}]^{+}$(calcd for $\mathrm{C}_{12} \mathrm{H}_{23} \mathrm{O}_{5} 247.1545$ ).

Diaporthsin F (6): colorless oil; $[\alpha]_{\mathrm{D}}^{23} 242.10$ (c 0.01, MeOH); IR (KBr) $\nu_{\max } 3431,2924,1734,1458 \mathrm{~cm}^{-1} .{ }^{1} \mathrm{H}$ NMR $(500 \mathrm{MHz})$ and ${ }^{13} \mathrm{C}$ NMR (125 MHz) in MeOD, see Table 2. HR-ESIMS $\mathrm{m} / \mathrm{z}$ 295.1161 [M $+\mathrm{Na}]^{+}$(calcd for $\mathrm{C}_{13} \mathrm{H}_{20} \mathrm{O}_{6} \mathrm{Na} 295.1158$ ).

Diaporthsin G (7): colorless oil; $[\alpha]_{\mathrm{D}}^{23} 234.69$ (c 0.014 , acetone); IR (KBr) $\nu_{\max } 3443,2925,1630,1384 \mathrm{~cm}^{-1} \cdot{ }^{1} \mathrm{H}$ NMR
(500 MHz) and ${ }^{13} \mathrm{C}$ NMR (125 MHz) in acetone- $\mathrm{d}_{6}$, see Table 3. HR-ESIMS $m / z \quad 227.1289[\mathrm{M}-\mathrm{H}]^{-}$(calcd for $\mathrm{C}_{12} \mathrm{H}_{19} \mathrm{O}_{4}$ 227.1283).

Diaporthsin H (8): white crystal; $[\alpha]_{\mathrm{D}}^{23} 73.14$ (c 0.04, MeOH); IR (KBr) $\nu_{\max } 3420,2926,1721,1362 \mathrm{~cm}^{-1} .{ }^{1} \mathrm{H}$ NMR (600 MHz) and ${ }^{13} \mathrm{C}$ NMR (150 MHz) in MeOD, see Table 3. HR-ESIMS $\mathrm{m} / \mathrm{z}$ $239.0938[\mathrm{M}+\mathrm{Na}]^{+}$(calcd for $\mathrm{C}_{10} \mathrm{H}_{16} \mathrm{O}_{5} \mathrm{Na} 239.0895$ ).

Diaporthsin I (9): colorless oil; $[\alpha]_{\mathrm{D}}^{23} 61.11$ (c 0.064, $\left.\mathrm{CDCl}_{3}\right)$; IR (KBr) $\nu_{\max } 3416,2924,1736,1377 \mathrm{~cm}^{-1} \cdot{ }^{1} \mathrm{H}$ NMR $(600 \mathrm{MHz})$ and ${ }^{13} \mathrm{C}$ NMR (150 MHz) in $\mathrm{CDCl}_{3}$, see Table 3. HR-ESIMS $\mathrm{m} / \mathrm{z}$ 239.1257 [M+Na $]^{+}$(calcd for $\mathrm{C}_{11} \mathrm{H}_{20} \mathrm{O}_{4} \mathrm{Na} 239.1259$ ).

Diaporthsin J (10): colorless oil; $[\alpha]_{\mathrm{D}}^{23} 332.90$ (c 0.01, acetone); IR (KBr) $\nu_{\max } 3447,2963,1631,1384 \mathrm{~cm}^{-1} .{ }^{1} \mathrm{H}$ NMR (600 MHz) and ${ }^{13} \mathrm{C}$ NMR $(150 \mathrm{MHz})$ in acetone- $\mathrm{d}_{6}$, see Table 4 . HR-ESIMS $m / z 253.1409[\mathrm{M}+\mathrm{Na}]^{+}$(calcd for $\mathrm{C}_{12} \mathrm{H}_{22} \mathrm{O}_{4} \mathrm{Na} 253.1416$ ).

Diaporthsin K (11): orange-red oil; $[\alpha]_{\mathrm{D}}^{23} 63.20$ (c 0.095 , $\mathrm{MeOH})$; IR (KBr) $\nu_{\max } 3426,2930,1730,1618,1384 \mathrm{~cm}^{-1}$. UV $(\mathrm{MeOH}) \lambda_{\max }(\log \varepsilon): 270$ (3.45) nm. ${ }^{1} \mathrm{H} \mathrm{NMR}(500 \mathrm{MHz})$ and ${ }^{13} \mathrm{C}$ NMR (125 MHz) in MeOD, see Table 4. HR-ESIMS $m / z 545.2720$ $[\mathrm{M}+\mathrm{Na}]^{+}$(calcd for $\mathrm{C}_{28} \mathrm{H}_{42} \mathrm{O}_{9} \mathrm{Na} 545.2727$ ).

\section{Antihyperlipidemic activity assay}

Steatosis hepatocyte L-02 cells $\left(3 \times 10^{5}\right.$ cells per well $)$ were seeded into 6-well microtiter plates (Corning) and divided into control, model, and treatment groups. The steatosis hepatocyte L-02 model was established by exposure to fat emulsion (5\%) for $48 \mathrm{~h}$. The resulting hepatocytes were treated with control or various concentrations of compounds for $24 \mathrm{~h}$; after culture, the cells were washed with PBS for two times and whole cell lysates were prepared by incubating in a cell lysis buffer (1\% Triton X100) for $30 \mathrm{~min}$ to extract total protein. Whole cell extracts were obtained by centrifugation for $10 \mathrm{~min}$. Protein concentrations were determined using the Bio-Rad microprotein assay with bovine serum albumin as the standard. The level of TG was detected by TG determination kit (Nanjing Jiancheng Bioengineering Institute, Nanjing, China).

\section{Cytotoxicity assay}

The cytotoxicities of these compounds against A-549 cells were determined in vitro by the MTT method. Cisplatin was used as a positive control with $\mathrm{IC}_{50}$ at $12.01 \mu \mathrm{M}$.

\section{Conflicts of interest}

The authors declare no conflict of interest.

\section{Acknowledgements}

This research work was financially supported by the National Natural Science Foundation of China $(81560571,81660582)$ and a project of Yunling Scholars of Yunnan Province.

\section{References}

1 J. H. Wang, Y. D. Zhang and J. P. Luo, Biotechnol. Biotechnol. Equip., 2018, 32, 744-750. 
2 A. Schueffler and T. Anke, Nat. Prod. Rep., 2014, 31, 14251448.

3 A. Evidente, A. Kornienko, A. Cimmino, A. Andolfi, F. Lefranc, V. Mathieu and R. Kiss, Nat. Prod. Rep., 2014, 31, 617-627.

4 R. R. Gomes, C. Glienke, S. I. Videira, L. Lombard, J. Z. Groenewald and P. W. Crous, Persoonia, 2013, 31, 1-41.

5 L. Sessa, E. Abreo, L. Bettucci and S. Lupo, Phytopathol. Mediterr., 2017, 56, 431-444.

6 Z. Liu, J. Y. Zhao, X. Liang, X. X. Lv, Y. Li, J. Qu and Y. B. Liu, Fitoterapia, 2018, 127, 7-14.

7 H. Cui, Y. N. Liu, J. Li, X. S. Huang, T. Yan, W. H. Cao, H. J. Liu, Y. H. Long and Z. G. She, J. Org. Chem., 2018, 83, 11804-11813.

8 K. I. Nakashima, J. Tomida, T. Kamiya, T. Hirai, Y. Morita, H. Hara, Y. Kawamura, T. Adachi and M. Inoue, Tetrahedron Lett., 2018, 59, 1212-1215.

9 C. Tanapichatsakul, S. Monggoot, E. Gentekaki and P. Pripdeevech, Curr. Microbiol., 2018, 75, 476-483.

10 C. J. Chen, X. X. Liu, W. J. Zhang, L. Y. Zang, G. Wang, S. W. Ng, R. X. Tan and H. M. Ge, RSC Adv., 2015, 5, 17559-17565.

11 S. Dettrakul, P. Kittakoop, M. Isaka, S. Nopichai, C. Suyarnsestakorn, M. Tanticharoenb and
Y. Thebtaranonth, Bioorg. Med. Chem. Lett., 2003, 13, 12531255.

12 Q. F. Tan, X. F. Yan, X. Lin, Y. J. Huang, Z. H. Zheng, S. Y. Song, C. H. Lu and Y. M. Shen, Helv. Chim. Acta, 2007, 90, 1811-1817.

13 S. Yoshida, T. Suzuki, H. Furuno, T. Aboshi, T. Murayama, T. Koseki and Y. Shiono, Nat. Prod. Res., 2018, 32, 60-64.

14 S. H. Wu, Y. W. Chen, S. C. Shao, L. D. Wang, Z. Y. Li, L. Y. Yang, S. L. Li and R. Huang, J. Nat. Prod., 2008, 71, 731-734.

15 Q. W. Tan, P. H. Fang, J. C. Ni, F. L. Gao and Q. J. Chen, Molecules, 2017, 22, 2073.

16 T. Kongprapan, X. Xu, V. Rukachaisirikul, S. Phongpaichit, J. Sakayaroj, J. Chen and X. Shen, Phytochem. Lett., 2017, 22, 219-223.

17 A. N. Matralis and A. P. Kourounakis, J. Med. Chem., 2014, 57, 2568-2581.

18 A. N. Matralis, M. G. Katselou, A. Nikitakis and A. P. Kourounakis, J. Med. Chem., 2011, 54, 5583-5591.

19 S. Grabley, E. Granzer, K. Hutter, D. Ludwig, M. Mayer, R. Thiericke, G. Till, J. Wink, S. Philipps and A. Zeeck, J. Antibiot., 1992, 45, 56-65. 